LA-9857-HDR

UC-66b

Issued: August 1983

LA- -9857-HDR

DE84 002293

\title{
Acord 1-26 Hot, Dry Well, Roosevelt Hot Springs Hot Dry Rock Prospect, Utah
}

Spencer S. Shannon, Jr.

Roland Pettitt

John Rowley

Fraser Goff

Mark Mathews

Jimmy J. Jacobson*

\section{DISCLAIMER}

This report was prepared as an account of work sponsored by an agency of the United States Government. Neither the United States Government nor any agency thereof, nor any of their employees, makes any warranty, express or implied, or assumes any legal liability or responsibility for the accuracy, completeness, or usefulness of any information, apparatus, product, or process disclosed, or represents that its use would not infringe privately owned rights. Reference herein to any specific commercial product, process, or service by trade name, trademark, manufacturer, or otherwise does not necessarily constitute or imply its endorsement, recommendation, or favoring by the United States Government or any agency thereof. The views and opinions of authors expressed herein do not necessarily state or reflect those of the United States Government or any agency thereof.

*MCR Geothermal Corporation, Irongate II, Suite 103, 777 S. Wadsworth Avenue, Lakewood, CO 80226 .
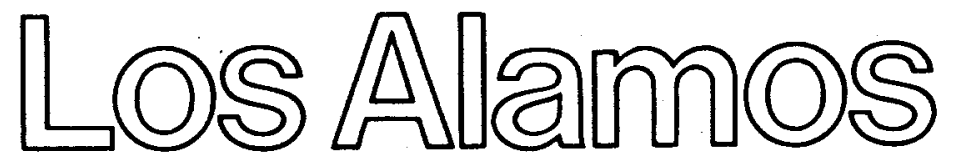


\section{DISCLAIMER}

This report was prepared as an account of work sponsored by an agency of the United States Government. Neither the United States Government nor any agency Thereof, nor any of their employees, makes any warranty, express or implied, or assumes any legal liability or responsibility for the accuracy, completeness, or usefulness of any information, apparatus, product, or process disclosed, or represents that its use would not infringe privately owned rights. Reference herein to any specific commercial product, process, or service by trade name, trademark, manufacturer, or otherwise does not necessarily constitute or imply its endorsement, recommendation, or favoring by the United States Government or any agency thereof. The views and opinions of authors expressed herein do not necessarily state or reflect those of the United States Government or any agency thereof. 


\section{DISCLAIMER}

Portions of this document may be illegible in electronic image products. Images are produced from the best available original document. 
ACORD 1-26 HOT, DRY WELL, ROOSEVELT HOT SPRINGS

HOT DRY ROCK PROSPECT, UTAH

by

Spencer S. Shannon, Jr., Roland Pettitt, John Rowley, Fraser Goff, Mark Mathews, and Jimmy J. Jacobson

\section{ABSTRACT}

The Acord 1-26 well is a hot, dry well peripheral to the Roosevelt Hot Springs known geothermal resource area (KGRA) in southwestern Utah. The bottom-hole temperature in this $3854-\mathrm{m}$-deep well is $230^{\circ} \mathrm{C}$, and the thermal gradient is $54^{\circ} \mathrm{C} / \mathrm{km}$. The basal $685 \mathrm{~m}$, comprised of biotite monzonite and quartz schist and gneiss, is a likely hot, dry rock (HDR) prospect. The hole was drilled in a structural low within the Milford Valley graben and is separated from the Roosevelt KGRA to the east by the Opal Mound Fault and other basin faults. An interpretation of seismic data approximates the subsurface structure around the well using the 1ithology in the Acord 1-26 well. The hole was drilled with a minimum of difficulty, and casing was set to $2411 \mathrm{~m}$. From drilling and geophysical logs, it is deduced that the subsurface blocks of crystalline rock in the vicinity of the Acord 1-26 well are tight, dry, shallow, impermeable, and very hot. A hydraulic fracture test of the crystalline rocks below $3170 \mathrm{~m}$ is recommended. Various downhole tools and techniques could be tested in promising HDR regimes within the Acord 1-26 we11.

\section{INTRODUCTION}

This report documents a hot, dry well near the margin of a known geothermal resource area (KGRA) in southwestern Utah. The intent is stimulation of interest in the development of additional sites for the generation of electricity from hot, dry rock (HDR).

The Acord 1-26 well is one of four hot, dry wells drilled around the western periphery of the production zone of the Roosevelt Hot Springs geothermal unit, Utah (Fig. 1). Because the Roosevelt Hot Springs area is 


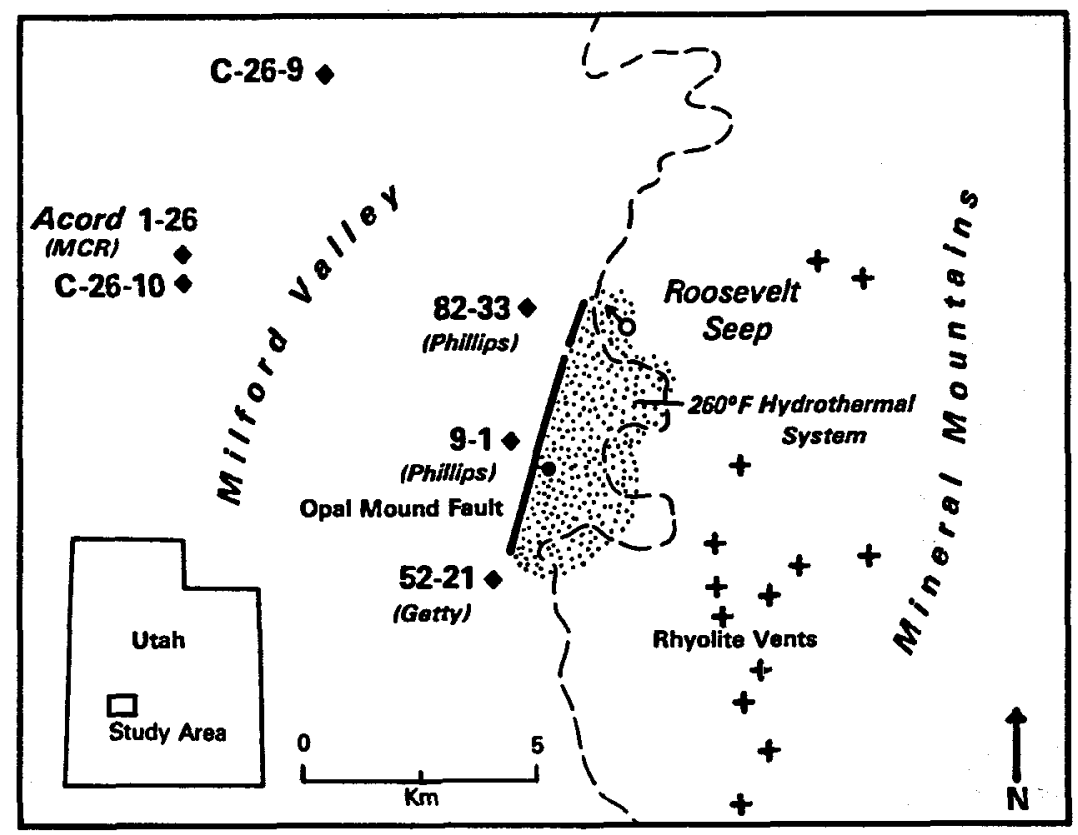

Fig. 1.

Location map of Roosevelt Hot Springs area, Utah, showing Opal Mound Fault, geothermal production zone, four hot, dry wells, and shallow, stock wells.

known to have high temperatures in impermeable crystalline basement rocks at relatively shallow depths, it has been the subject of several Los Alamos investigations on HDR (East 1981; Goff and Decker 1983; F. D. Vuataz and F. Goff, unpub. data, 1983).

\section{SETTING}

The Acord 1-26 hot, dry well was drilled in spring 1979 by McCullough Geothermal Corporation in C, SW 1/4 sec. 26, T. 26 S., R. 10 W., Salt Lake Meridian. This site is in Beaver County, Utah, approximately $15 \mathrm{~km}$ north-northeast of Milford and $8 \mathrm{~km}$ west-northwest of the Roosevelt Hot Springs geothermal field. The well site is $3.6 \mathrm{~km}$ east of a paved highway and $3.2 \mathrm{~km}$ east of a main line of the Union Pacific Railroad. Local relief is low where the well is collared in lake sediments in Milford Valley. The well has a depth of $3.85 \mathrm{~km}$ and a recorded bottom-hole temperature of $230^{\circ} \mathrm{C}$.

East (1981) has prepared a detailed discussion of the regional geological and geophysical setting of the Roosevelt Hot Springs area including the Acord 1-26 well, which is on the periphery of this KGRA. The following generalizations are derived from her paper. 
The Milford Valley and adjoining Roosevelt Hot Springs are in the transition zone between the Basin and Range and Colorado Plateau provinces. Within this zone the crust is only $25 \mathrm{~km}$ thick and the $P_{n}$ velocity is only $7.5 \mathrm{~km} / \mathrm{s}$. The depth of the crustal low-velocity layer in the transition zone varies from 8 to $15 \mathrm{~km}$. The area of interest is near the western edge of the Intermountain seismic belt where its trend turns from northeast to north.

Typically, heat flow averages 2.2 heat-flow units (HFU) in the Basin and Range province and only $1.2 \mathrm{HFU}$ in the Colorado Plateau province. However, the high heat-flow characteristic of the Basin and Range province extends eastward beyond the provincial boundary. Futhermore, the Acord 1-26 well and the Roosevelt Hot Springs area are along the margin of the southern region of elevated heat flow where values typically are $2.5 \mathrm{HFU}$.

The Roosevelt Hot Springs hydrothermal system circulates in a faulted graben east of the Opal Mound (Dome) Fault (Fig. 1) at temperatures of 260 to $320^{\circ} \mathrm{C}$. Although the regional heat flow is high, local heat sources as indicated by basaltic cinder cones north of Roosevelt Hot Springs, are also present as young as 0.1 Myr. Also 0.8-to-0.5-Myr rhyolitic magma erupted from a chain of vents along the axis of the Mineral Mountains to the east. Thus, the thermal anomaly and hydrothermal system may be driven partially by Quaternary volcanic processes.

\section{GEOLOGY}

In stratigraphic succession, the geology of the Acord well includes $30 \mathrm{~m}$ of metamorphic rocks, $655 \mathrm{~m}$ of plutonic rocks, $700 \mathrm{~m}$ of coarse sedimentary rocks, $315 \mathrm{~m}$ of volcanic rocks, and $2155 \mathrm{~m}$ of sedimentary rocks and sediments (Fig. 2).

The bottom $30 \mathrm{~m}$ comprise white to dark-gray migmatitic quartz schist and gneiss containing abundant potassium feldspar, plagioclase, biotite, and muscovite. Locally the rock is altered to chlorite or epidote. This could be a major inclusion in the monzonite pluton described next.

Above the schist and gneiss are $655 \mathrm{~m}$ of white to green propylitized biotite monzonite. Some fragments of biotite-chlorite schist remain 6 to $9 \mathrm{~m}$ above the base of the plutonic rock and a residual block of light-orange quartzite is 18 to $20 \mathrm{~m}$ higher in the section. Also, a 4-m-thick bed of light orange-pink quartzite occurs $90 \mathrm{~m}$ above the base of the plutonic rock. 


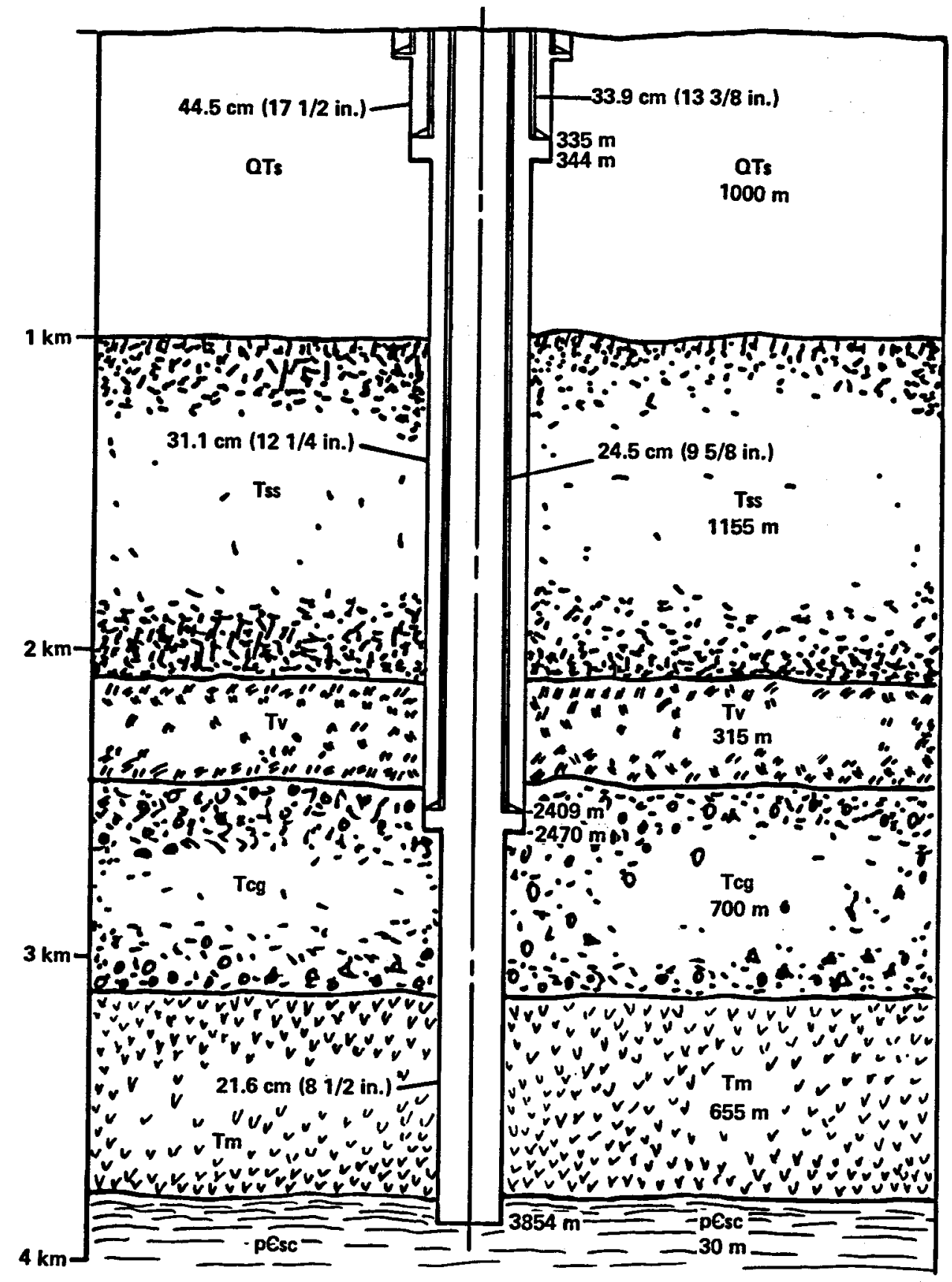

Fig. 2.

Generalized stratigraphy of an east-west section through the Milford Valley.

The 700-m interval above the quartz monzonite pluton is made up of conglomerate and some sandstone. The clasts in the basal $135 \mathrm{~m}$ of the conglomerate are composed chiefly of chloritized white to green volcanic rock and gray-brown siltstone. The remainder of this section contains clasts of 
light-green sandstone, reddish-brown volcanic rock (chiefly altered basalt), and a small amount of light-brown dolomite.

A suite of volcanic rocks follow, which has a total thickness of $315 \mathrm{~m}$. The basal unit is $73 \mathrm{~m}$ of basalt containing amygdaloidal epidote. Above this, in turn, are $58 \mathrm{~m}$ of light-pink porphyritic rhyolite, $150 \mathrm{~m}$ of medium-gray to reddish-brown dacite, and $34 \mathrm{~m}$ of dark-gray andesite.

overlying the volcanic rocks are $390 \mathrm{~m}$ of white, brown, and green sandstone that chiefly has a volcanic provenance, $135 \mathrm{~m}$ of light- to reddish-brown siltstone, and $320 \mathrm{~m}$ of varicolored, poorly sorted arkosic sandstone and conglomerate containing granules and pebbles mostly composed of andesite and basalt.

Next in the sequence is $190 \mathrm{~m}$ of reddish-brown sandy claystone containing some pebbles of quartz monzonite. This is overlain by a $120-m$ wedge of clastic strata, namely, $37 \mathrm{~m}$ of sandstone and conglomerate, $56 \mathrm{~m}$ of reddishbrown siltstone and silty claystone, and $27 \mathrm{~m}$ of light-brown silty sandstone.

The uppermost kilometer of sediments in the Acord well is composed predominantly of lacustrine clay. About $363 \mathrm{~m}$ of light-brown claystone are overlain by $565 \mathrm{~m}$ of light bluish-gray calcareous claystone, which contains abundant selenite crystals. Several thin $(10-$ to $25-\mathrm{m})$ light-brown locally gypsiferous sandstones are intercalated at and near the lower and upper limits of the bluish-gray claystone sequence.

The Milford Valley is a complex graben bounded by normal faults. An elongated north-trending gravity low centered northeast of Milford is evidence that the graben may be filled with alluvium (Group Seven 1978). Intrusive rock of Tertiary age underlies most of the Milford Valley (East 1981). The channel of the Beaver River in the vicinity of the Acord 1-26 well is entrenched $6 \mathrm{~m}$ because of local uplift (Mower and Cordoba 1974).

According to Davis (1980), the Acord 1-26 well was drilled in a structural low or synform (Fig. 3). The well site may be along the northwestern projection of the Hot Springs Fault from the Roosevelt Hot Springs area. In the vicinity of the Acord 1-26 well, the dominant north-northeast trending faults extend into the basement. There is a local zone of faulting within the basin immediately east and northeast of the Acord 1-26 well. Approximately 1 $\mathrm{km}$ of movement along the major northeast-trending fault, which is less than $400 \mathrm{~m}$ east of the Acord 1-26 we11, may have caused the fracture zones below $3.6 \mathrm{~km}$ in the basement rock intersected by the well. Motion along several 
$\mathbf{N}$

Section A-1

$\mathbf{s}$

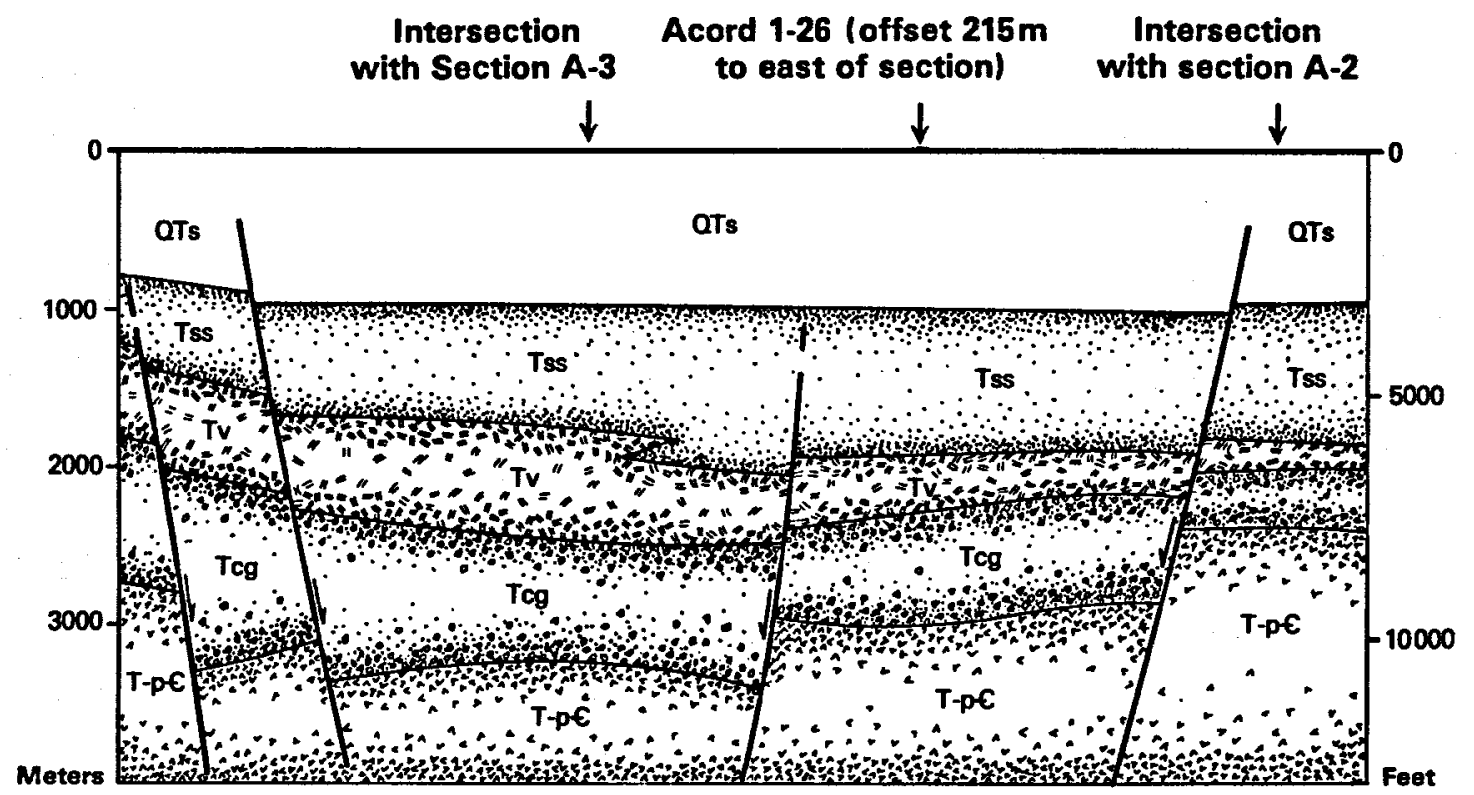

$\mathbf{w}$

Section A-2

E

Intersection

with Section A-1

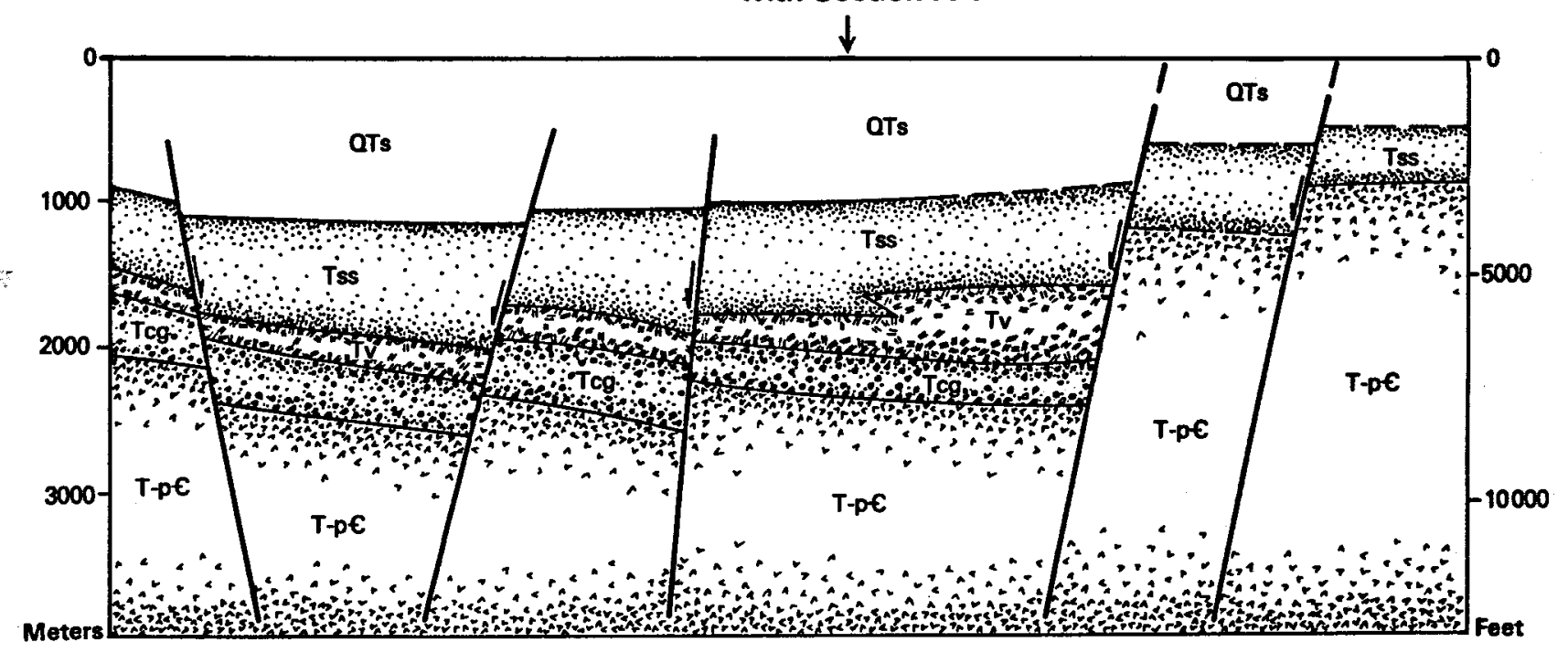

Fig. 3.

Interpretation of three seismic reflection traverses (courtesy of MCR Geothermal Corporation) based on model of Davis (1980) and stratigraphy of Acord 1-26 wel1. 


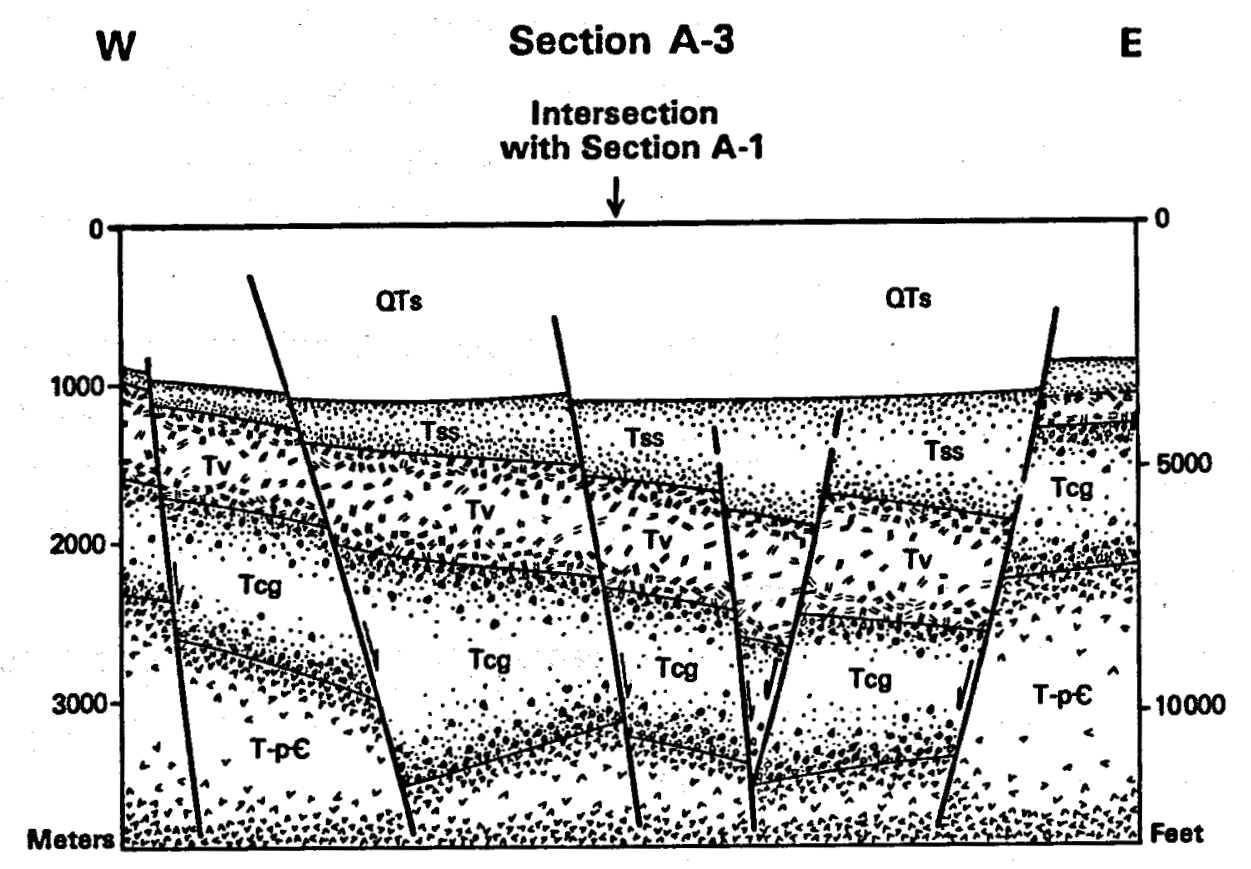

Generalized Stratigraphy
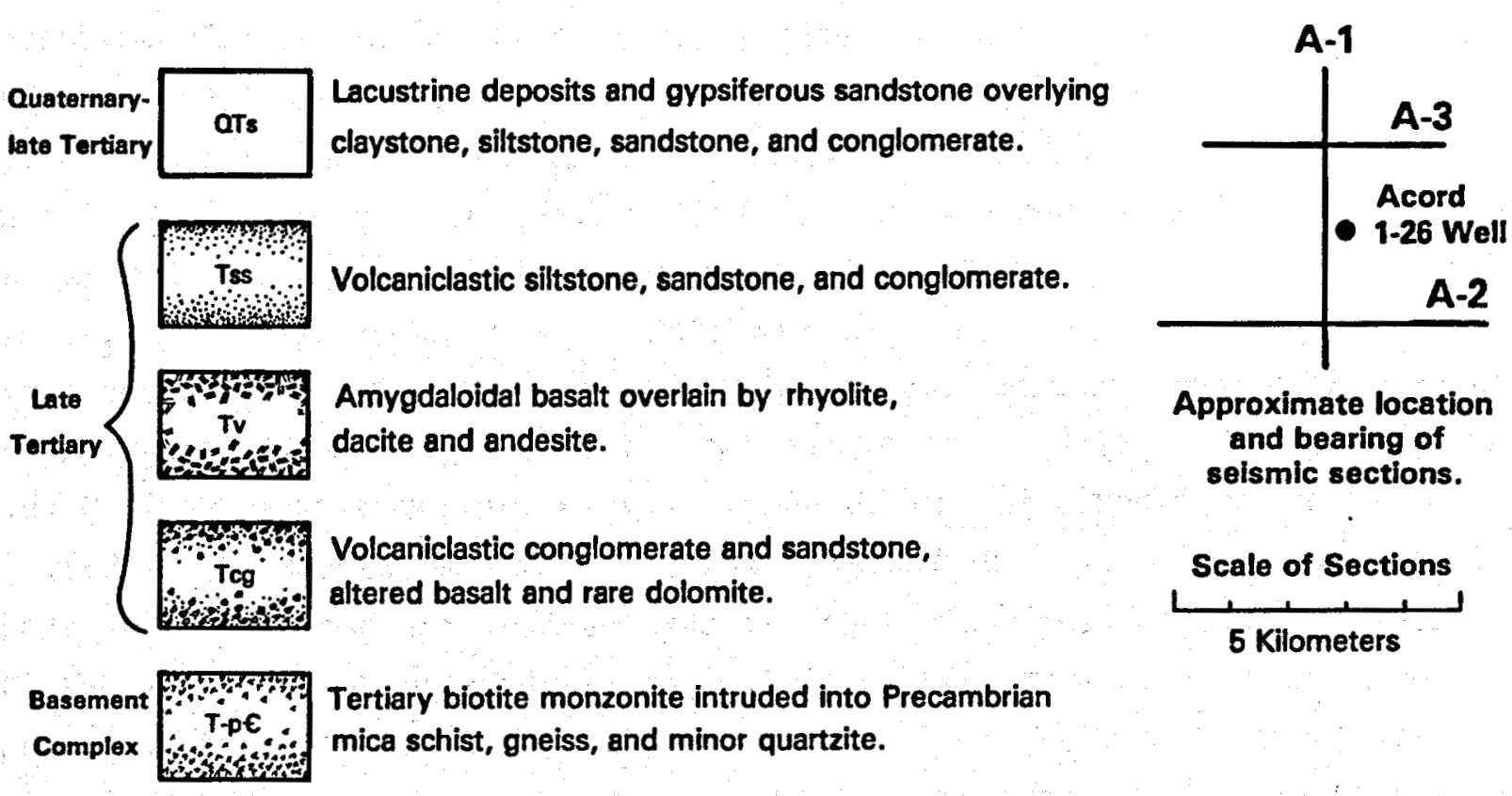

Fig. 3. (cont) 
major faults approximately $1.2 \mathrm{~km}$ north-northeast of the Acord well along the northern boundary of section 26 may have caused extensive fracturing and faulting of basement rocks. Another possible fault zone is in the extreme southeastern corner of the township approximately $3 \mathrm{~km}$ southeast of the Acord 1-26 well.

The structural interpretation of Davis shows the late Tertiary volcanic sequence thickens to the north and west of the Acord well. Because the volcanics are very thin or absent above the basement high to the east, much of the offset along the major fault east of the Acord well is inferred to have taken place before or contemporaneously with volcanism.

If hydrothermal fluids occur in sedimentary and volcanic rocks above basement, they probably have limited volume and are trapped adjacent to the major fault zone east of the Acord well.

\section{HYDROLOGY}

Both surface and subsurface water in Utah are allocated by the Utah Department of Natural Resources. MCR Geothermal Corporation has no surface water rights in or near sec. 26, T. 26 S., R. $10 \mathrm{~W}$. Most of the ground water in the Milford, Utah area is in coarse, poorly consolidated basinal sediments within $150 \mathrm{~m}$ of the surface corresponding to the upper sandstones in the geologic log of the Acord 1-26 well. The L. Kant Anderson water well (C-26-10) 26 had a measured water level $25 \mathrm{~m}$ deep in May 1982. A second Anderson water well $(C-26-9) 13,5 \mathrm{~km}$ northeast of the Acord 1-26, also had a measured water level $25 \mathrm{~m}$ deep in May 1982. Both water wells had yields exceeding $1500 \mathrm{l} / \mathrm{min}$ during spring 1983. A Los Alamos National Laboratory pumping test will be made on one of the two wells to determine if enough water is available for circulation in an HDR energy extraction system of $50 \mathrm{MW}(\mathrm{e})$ (information provided by F. D. Vuataz, Los Alamos National Laboratory, 1983).

The decline in water-table level in this part of the basin was less than $3 \mathrm{~m}$ during the period from 1950 to 1972 . The Beaver River commonly is dry in proximity to the Acord 1-26 well because its water has been diverted upstream for irrigation. A stream that heads $0.7 \mathrm{~km}$ northwest of the Acord 1-26 well is ephemera1. It trends northwestward from the Acord 1-26 we11, but terminates in sand dunes before reaching the intermittent Beaver River $6 \mathrm{~km}$ away. 
Some water was intersected within $1 \mathrm{~km}$ of the surface in poorly consolidated alluvial sediments of Quaternary age. Essentially no water was found deeper in the Acord 1-26 wel1; even the fracture zones were dry.

\section{GEOPHYSICS}

Using seismic data, Davis estimated the top of the basement in the Acord 1-26 well to be at a depth of 2.83 to $2.9 \mathrm{~km}$, which is $10 \%$ too shallow. The estimated depth to the crystalline basement based on magnetic data is about $1.5 \mathrm{~km}$ (Group Seven 1979), but the contact in the well is twice as deep. Our revised cross-sections (Fig. 3) are based on contact relations and depths observed in the Acord well as well as on the seismic interpretation of Davis.

In Beaver Bottoms, $6 \mathrm{~km}$ northwest of the Acord 1-26 well, aeromagnetic data have been used to postulate a depth of 2.5 to $5 \mathrm{~km}$ to basement. However, a large magnetotelluric anomaly, no magnetization, and low resistivity there could be because of temperature effects or clays. The depth to basement is greatest along the north-trending Milford Valley axis. The valley fill is deeper both north and south of a hingeline in T27S, R1OW, which is $8 \mathrm{~km}$ south of the Acord 1-26 well. In contrast, along an east-west aeromagnetic profile through the Acord 1-26 well, the depth of the basement contact is estimated to be 300 to $1500 \mathrm{~m}$ (East 1981).

VI. DRILLING HISTORY

A. Drilling

The well was spudded on March 30, 1979, and drilling proceeded largely without incident to the total depth of $3854 \mathrm{~m}(12645 \mathrm{ft})$ on June 5, 1979. The drilling contractor was Republic Drilling Company; the rig consisted of a GB-800 EMSCO draw works, an IDECO Full View $40.5 \mathrm{~m}$ (133 ft) mast, powered by two D-379 Caterpillar engines.

Drilling began with a $44.5-\mathrm{cm}-$ diam Smith DST milled-tooth bit and proceeded at an average penetration rate of $11 \mathrm{~m} / \mathrm{h}$ to a depth of $344 \mathrm{~m}$ (1129 ft). (See Table I for a summary of the drilling record.) After the $33.9-\mathrm{cm}$ casing was set to $335 \mathrm{~m}(1100 \mathrm{ft})$, drilling continued with $31.1-\mathrm{cm}$ Smith DT bit at an average penetration rate of $15 \mathrm{~m} / \mathrm{h}$. During the next bit run, the penetration rate decreased by about one-third, even though the load on the bit was increased to $9 \mathrm{t}$ and the rotational speed was held at $74 \mathrm{rpm}$. During bit run No. 4 , the bit load was increased to $14 \mathrm{t}$ and the rotational speed decreased 
TABLE I

SUMMARY OF DRILLING RECORD FOR ACORD WELL I-26

\begin{tabular}{|c|c|c|c|c|c|c|c|c|c|c|c|c|c|c|c|}
\hline $\begin{array}{l}\text { Bit } \\
\text { Mo. } \\
\end{array}$ & $\begin{array}{l}\text { Size } \\
(\text { in) } \\
\end{array}$ & Make & Type & $\begin{array}{c}\text { Depth } \\
\text { Out } \\
\text { (ft) } \\
\end{array}$ & $\begin{array}{c}\text { Footage } \\
(\mathrm{ft})\end{array}$ & $\begin{array}{c}\text { Mours } \\
\text { (hr) } \\
\end{array}$ & $\begin{array}{l}\text { Pen. } \\
\text { Rate } \\
\text { (fe/hr) } \\
\end{array}$ & $\begin{array}{r}\text { Max. } \\
\text { Bit } \\
(1000 \text { Yos }) \\
\end{array}$ & $\begin{array}{c}10 / 1 n \\
\text { dia }\end{array}$ & RPM & $\begin{array}{c}\text { Pump } \\
\text { Pressure } \\
\text { (psi) } \\
\end{array}$ & $\begin{array}{l}\text { Mud } \\
\text { Meight } \\
\text { (1b/gal) }\end{array}$ & $\underline{\text { VIS }}$ & PY & Renarks \\
\hline 1 & $171 / 2$ & Surith & DSJ & 1129 & 1084 & 29.5 & 37 & $5-10$ & 571 & $50-62$ & 750 & 8.8 & 43 & 5 & $133 / 8=$ Casing \\
\hline $\begin{array}{l}2 \\
3 \\
4 \\
5 \\
6 \\
7 \\
8 \\
R R B \\
9\end{array}$ & $\begin{array}{ll}12 & 1 / 4 \\
12 & 1 / 4 \\
12 & 1 / 4 \\
12 & 1 / 4 \\
12 & 1 / 4 \\
12 & 1 / 4 \\
12 & 1 / 4 \\
12 & 1 / 4 \\
12 & 1 / 4\end{array}$ & $\begin{array}{l}\text { Sinith } \\
\text { Sinith } \\
\text { Sinith } \\
\text { Sinith } \\
\text { sinith } \\
\text { Simith } \\
\text { Sinith } \\
\text { Smith } \\
\text { Sith }\end{array}$ & $\begin{array}{l}\text { OT } \\
\text { OGT } \\
\text { F3 } \\
\text { F3 } \\
\text { DTJ } \\
\text { DTJ } \\
\text { F3 } \\
\text { F3 } \\
\text { F4 }\end{array}$ & $\begin{array}{l}3433 \\
3999 \\
5271 \\
5484 \\
5980 \\
6250 \\
6716 \\
7288 \\
7919\end{array}$ & $\begin{array}{l}2304 \\
566 \\
1272 \\
213 \\
496 \\
270 \\
466 \\
569 \\
631\end{array}$ & $\begin{array}{l}46.75 \\
32.5 \\
65.75 \\
28.0 \\
28.25 \\
14.25 \\
25.75 \\
28.25 \\
36.0\end{array}$ & $\begin{array}{l}49 \\
17 \\
19 \\
8 \\
18 \\
19 \\
18 \\
20 \\
18\end{array}$ & $\begin{array}{l}10-12 \\
15-20 \\
30 \\
30 \\
35 \\
30 \\
30-32 \\
35 \\
25-30\end{array}$ & $\begin{array}{l}980 \\
1633 \\
2450 \\
2450 \\
2857 \\
2450 \\
2612 \\
2857 \\
2450\end{array}$ & $\begin{array}{l}50-74 \\
74 \\
40-46 \\
40 \\
66 \\
63 \\
48 \\
46 \\
45\end{array}$ & $\begin{array}{l}1600 \\
1800 \\
1225 \\
1200 \\
1350 \\
1200 \\
1200 \\
1300 \\
1250\end{array}$ & $\begin{array}{l}8.6 \\
8.8 \\
9.2 \\
9.4 \\
9.1 \\
9.2 \\
9.2 \\
9.2 \\
9.1\end{array}$ & $\begin{array}{l}33 \\
33 \\
34 \\
38 \\
36 \\
34 \\
34 \\
34 \\
36\end{array}$ & $\begin{array}{l}6 \\
7 \\
4 \\
9 \\
-2 \\
4 \\
7 \\
6\end{array}$ & $\begin{array}{l}\text { Losing } 20 \mathrm{bbl} / \mathrm{hr} \\
\text { Losing } 10 \mathrm{bbl} / \mathrm{hr} \\
\text { Reduced RPM } \\
40 \mathrm{ft} \text { of fill } \\
\text { Losing } 15 \mathrm{bbl} / \mathrm{hr} \\
\text { Losing } 10 \mathrm{bbl} / \mathrm{hr} \\
95 / 8^{\circ} \mathrm{Casing} \text { set } \\
\text { to } 7904 \mathrm{ft}\end{array}$ \\
\hline $\begin{array}{l}10 \\
11 \\
12 \\
13\end{array}$ & $\begin{array}{ll}8 & 1 / 2 \\
8 & 1 / 2 \\
8 & 1 / 2 \\
8 & 1 / 2\end{array}$ & $\begin{array}{l}\text { Sinith } \\
\text { Mughes } \\
\text { Swith } \\
\text { Hughes }\end{array}$ & $\begin{array}{l}\text { DGH } \\
\text { J44 } \\
\text { F4 } \\
\text { J44 }\end{array}$ & $\begin{array}{l}8115 \\
9001 \\
9228 \\
9563\end{array}$ & $\begin{array}{l}196 \\
886 \\
228 \\
334\end{array}$ & $\begin{array}{l}11.25 \\
81.5 \\
21.5 \\
34.25\end{array}$ & $\begin{array}{l}17 \\
11 \\
11 \\
10\end{array}$ & $\begin{array}{l}25-30 \\
30 \\
30 \\
30\end{array}$ & $\begin{array}{l}\mathbf{3 5 3 0} \\
\mathbf{3 5 3 0} \\
\mathbf{3 5 3 0} \\
\mathbf{3 5 3 0}\end{array}$ & $\begin{array}{l}45 \\
56-60 \\
56-60 \\
50\end{array}$ & $\begin{array}{l}-- \\
900 \\
900 \\
1000\end{array}$ & $\begin{array}{l}\ddot{8.8} \\
\ddot{9.0}\end{array}$ & $\begin{array}{l}\ddot{35} \\
35\end{array}$ & $\begin{array}{l}\ddot{3} \\
\ddot{4}\end{array}$ & $\begin{array}{l}\text { Mo mud loss } \\
\text { Twist-off at } 9230 \\
\text { ft }\end{array}$ \\
\hline $\begin{array}{l}14 \\
15\end{array}$ & $\begin{array}{l}81 / 2 \\
81 / 2\end{array}$ & $\begin{array}{l}\text { Santen } \\
\text { Salth }\end{array}$ & $\begin{array}{l}\mathbf{F 3} \\
\mathbf{F 3}\end{array}$ & $\begin{array}{l}9988 \\
10414\end{array}$ & $\begin{array}{l}425 \\
426\end{array}$ & $\begin{array}{l}52.0 \\
49.5\end{array}$ & $\stackrel{8}{9}$ & $\begin{array}{l}20 \\
20\end{array}$ & $\begin{array}{l}2350 \\
2350\end{array}$ & $\begin{array}{l}66 \\
66\end{array}$ & $\begin{array}{l}1050 \\
1050\end{array}$ & $\begin{array}{l}9.0 \\
9.1\end{array}$ & $\begin{array}{l}36 \\
36\end{array}$ & $\begin{array}{l}3 \\
5\end{array}$ & $\begin{array}{l}\text { Wo aud loss } \\
\text { Lost } 3-10 \mathrm{bb} 1 \mathrm{~s} / \mathrm{hr} \\
\text { from } 10,260 \text { to } \\
10,350 \mathrm{ft}\end{array}$ \\
\hline $\begin{array}{l}16 \\
17 \\
18 \\
19 \\
20 \\
21 \\
22 \\
23\end{array}$ & $\begin{array}{ll}8 & 1 / 2 \\
8 & 1 / 2 \\
6 & 1 / 2 \\
8 & 1 / 2 \\
8 & 1 / 2 \\
8 & 1 / 2 \\
8 & 1 / 2 \\
8 & 1 / 2\end{array}$ & 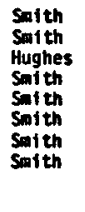 & $\begin{array}{l}F 4 \\
F 4 \\
544 \\
F 5 \\
\text { WS } \\
\text { WSS } \\
\text { WS } \\
\text { WS }\end{array}$ & $\begin{array}{l}10559 \\
10897 \\
11111 \\
11321 \\
11451 \\
11681 \\
11916 \\
12143\end{array}$ & $\begin{array}{l}245 \\
238 \\
214 \\
210 \\
130 \\
230 \\
235 \\
227\end{array}$ & $\begin{array}{l}24.0 \\
23 \\
23.75 \\
28.0 \\
15.5 \\
24.0 \\
25.0 \\
26.0\end{array}$ & $\begin{array}{l}10 \\
10 \\
9 \\
8 \\
8 \\
10 \\
9 \\
9\end{array}$ & $\begin{array}{l}20 \\
20 \\
25 \\
25 \\
25 \\
25 \\
25 \\
25\end{array}$ & $\begin{array}{l}2350 \\
2350 \\
2940 \\
2940 \\
2940 \\
2940 \\
2940 \\
2940\end{array}$ & $\begin{array}{l}59 \\
60 \\
40 \\
40 \\
40 \\
40 \\
40 \\
52\end{array}$ & $\begin{array}{l}1000 \\
1000 \\
1000 \\
1000 \\
1000 \\
1000 \\
1000 \\
1100\end{array}$ & \begin{tabular}{l}
9.2 \\
9.2 \\
9.2 \\
\hdashline.- \\
$\overline{9.1}$ \\
$\ddot{9.1}$
\end{tabular} & \begin{tabular}{l}
36 \\
36 \\
45 \\
\hdashline- \\
35 \\
$\ddot{38}$
\end{tabular} & $\begin{array}{l}7 \\
7 \\
5 \\
\because- \\
7 \\
\ddot{10}\end{array}$ & $\begin{array}{l}\mathrm{CO}_{2} \text { Content in wid } \\
38,000,000 \text { to }\end{array}$ \\
\hline $\begin{array}{l}24 \\
25 \\
26\end{array}$ & $\begin{array}{ll}8 & 1 / 2 \\
8 & 1 / 2 \\
8 & 1 / 2\end{array}$ & $\begin{array}{l}\text { Solth } \\
\text { Hughes } \\
\text { Seith }\end{array}$ & $\begin{array}{l}F 4 \\
j 44 \\
F 7\end{array}$ & $\begin{array}{l}12336 \\
12561 \\
12645\end{array}$ & $\begin{array}{l}193 \\
225 \\
84\end{array}$ & $\begin{array}{l}24.25 \\
26.5 \\
12\end{array}$ & $\begin{array}{l}8 \\
9 \\
7\end{array}$ & $\begin{array}{l}25 \\
\cdots \\
--\end{array}$ & $\begin{array}{l}2940 \\
=- \\
--\end{array}$ & $\begin{array}{l}52 \\
-- \\
--\end{array}$ & $\begin{array}{l}1000 \\
--\end{array}$ & $\begin{array}{l}= \\
=\end{array}$ & $\begin{array}{l}= \\
=\end{array}$ & $\ddot{\because}$ & $\mathrm{CO}_{2}$ content : \\
\hline
\end{tabular}

to 40-46 rpm, resulting in a greatly increased time on bottom. Drilling of the $31.1-\mathrm{cm}$ hole continued through mixed strata of conglomerate, claystone, and partly consolidated sands to a depth of $2155 \mathrm{~m}(7100 \mathrm{ft})$ where the volcanic rocks begin; on to a depth of $2414 \mathrm{~m}(7919 \mathrm{ft})$, where the 24.5-cm casing was set.

Drilling below $2414 \mathrm{~m}(7919 \mathrm{ft})$ was done with 21.6-cm bits, mostly Smith F3 and F4, plus a few Hughes $\mathrm{j} 44$ bits. The average penetration rate through the predominately conglomerate and monzonite sequence in the lower section of the hole was $2.8 \mathrm{~m} / \mathrm{h}$ at a bit load of 9 to $11 \mathrm{t}$, at 40 to $60 \mathrm{rpm}$. The only trouble occurred at 2813-m $(9230-f t)$ depth, where the drill pipe twisted off leaving 17 drill collars in the hole. These were retrieved, however, on the first fishing attempt. In general, the drilling progressed very smoothiy, taking 68 days and averaging $56.7 \mathrm{~m}$ (186 ft) per day.

B. Drilling Fluids

The initial mud mixture, to a depth of $2536 \mathrm{~m}(8320 \mathrm{ft})$, was bentonite and water. In the upper $2195 \mathrm{~m}(7200 \mathrm{ft})$ of the hole, mud losses were often 1.6 to $4.8 \mathrm{kl} / \mathrm{h}$, with mica and nut plug being added as lost-circulation materials. Below $2536 \mathrm{~m}(8320 \mathrm{ft})$, a Geo-Gel (sepiolite) mud was used. 
Throughout the drilling, the mud weight was kept between 1080 and $1100 \mathrm{~g} / \mathrm{l}$, at a viscosity of 34 to $38 / \mathrm{s}$.

C. Casing

Casing data for the well are summarized as follows:

\begin{tabular}{|c|c|c|c|c|c|c|}
\hline $\begin{array}{l}\text { Casing } \\
\text { Size } \\
\mathrm{cm}(\mathrm{in} .)\end{array}$ & $\mathrm{kg} / \mathrm{m}^{h}$ & $\begin{array}{l}\text { ight } \\
\text { (1bs/ft) }\end{array}$ & Type & Thread & $\begin{array}{l}\text { Length } \\
\mathrm{m}(\mathrm{ft})\end{array}$ & $\begin{array}{l}\text { Set } \\
\text { Depth } \\
m(f t)\end{array}$ \\
\hline $\begin{array}{l}33.9 \\
24.5 \quad(13-3 / 8) \\
(9-5 / 8)\end{array}$ & $\begin{array}{l}81 \\
70 \\
70 \\
60 \\
60\end{array}$ & $\begin{array}{l}54.5 \\
47.0 \\
43.5 \\
40.0 \\
40.0\end{array}$ & $\begin{array}{l}K-55 \\
N-80 \\
N-80 \\
L-80 \\
K-55\end{array}$ & $\begin{array}{l}\text { Buttress } \\
\text { Buttress } \\
\text { Buttress } \\
\text { Buttress } \\
\text { Buttress }\end{array}$ & $\begin{array}{ll}335 & (1100) \\
397 & (1300) \\
465 & (1526) \\
770 & (2524) \\
779 & (2554)\end{array}$ & $335(1100)$ \\
\hline
\end{tabular}

D. Cementing

Both the $33.9-\mathrm{cm}$ and $24.5-\mathrm{cm}$ casing strings were cemented full length, from the casing shoe to the ground surface. The cement slurry was composed of Class $G$ cement, containing $40 \%$ silica flour and $1: 1$ perlite.

\section{LOG INTERPRETATION}

Figure 4 records the mud $\log$ and geophysical logs run in the Acord 1-26 well. The depth intervals, data, and comments on data are included. The logs and primary interpretation results are described below.

A temperature $\log$ was run on April 21, 1979, $36 \mathrm{~h}$ after the last mud circulation. The zone from 2400 to $3701 \mathrm{~m}$ has an essentially linear temperature profile and little sign of even slight lost circulation zones or fluid entry points. This indicated gradient implies a $150 \mathrm{MW} / \mathrm{m}^{2}$ conductive heat flow (East 1981). On May 29, 1979, another temperature log was run $26.5 \mathrm{~h}$ after circulation. It confirms the earlier $\log$ and shows a bottom-hole static temperature of at least $230^{\circ} \mathrm{C}$.' Logging depths were 2408 to $3701 \mathrm{~m}$. Differential temperature and temperature logs were run on May 21, 1979. Two logging runs from 1220 to $3475 \mathrm{~m}$ have a constant and essentially featureless differential temperature profile. On the mud $10 \mathrm{~g}$, monzonite begins at $3170 \mathrm{~m}$ and goes to a total depth of $3854 \mathrm{~m}$.

The velocity or acoustic $\log$ was run from 3170 to $3487 \mathrm{~m}$. Over the bottom 30 to $45 \mathrm{~m}$ there is a possible temperature problem with the logging tool. The caliper $\log$ shows a washout from 3456 to $3459 \mathrm{~m}$. This caliper $\log$ was recorded with the temperature log; therefore the log obtained going down 


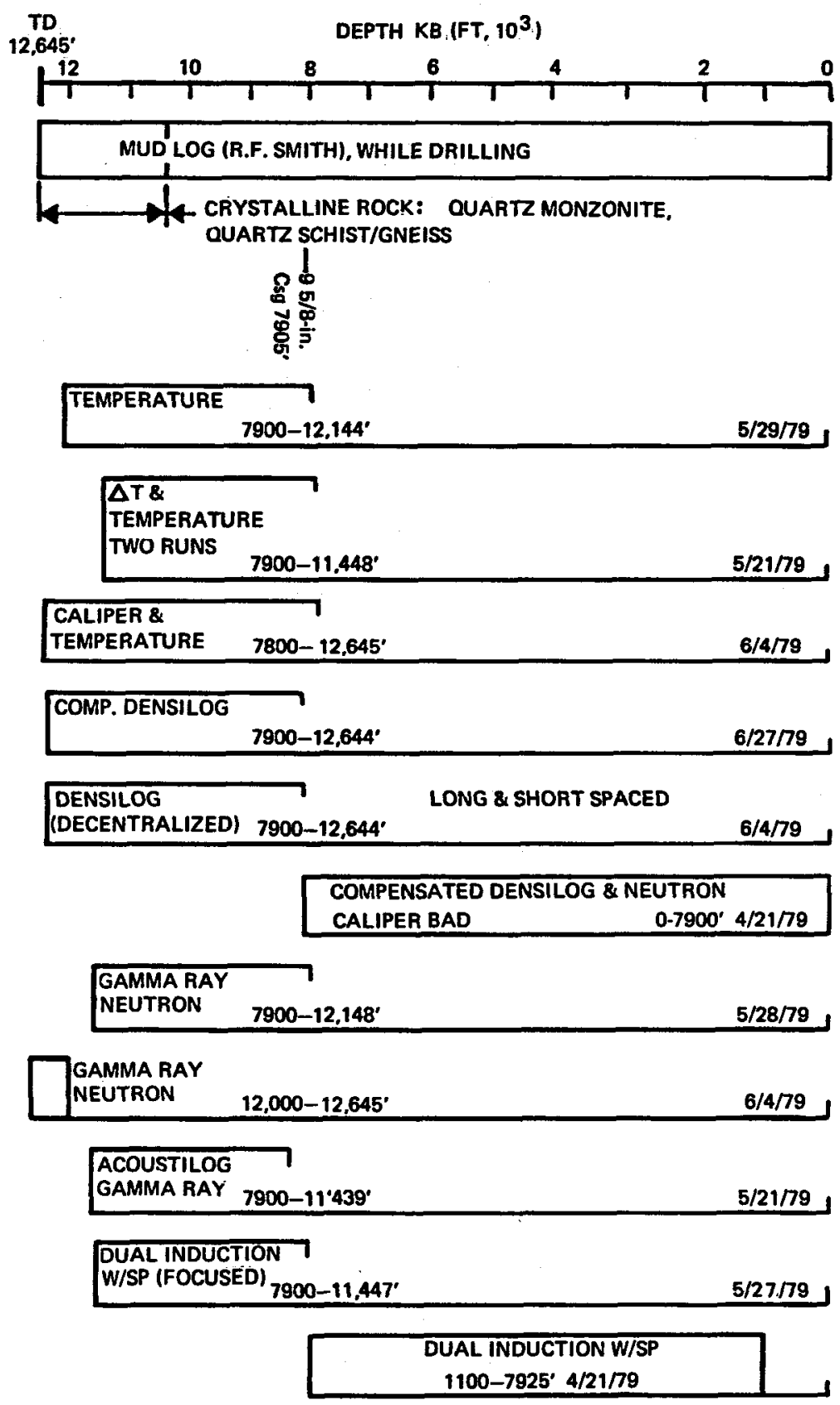

ALL GEOPHYSICAL LOGGING BY DRESSER ATLAS

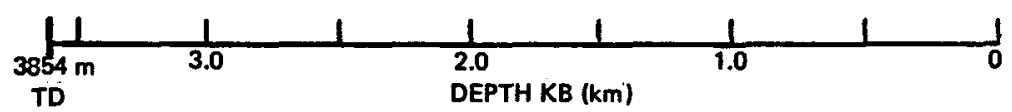

Fig. 4 .

Summary of well logs, Acord 1-26 well, Roosevelt Hot Springs area, Utah. 
the well is in error. The washout seen on the velocity or acoustic log is from 3162 to $3165 \mathrm{~m}$. The $\Delta t$ ranges from 17 to $18 \mu \mathrm{s} / \mathrm{m}(5.60$ to $5.09 \mathrm{~km} / \mathrm{s})$ in the depth interval from 3170 to $3487 \mathrm{~m}$. The mostly competent rock has a few $\Delta$ spikes, which may indicate fractures or tool decentralization.

The log recorded with the gamma-ray tool has a zone of high count rate. One explanation is that the amount of potassic granitic rock increases where a sill or dike was injected into the country rock. Another is that old fractures were healed with uraniferous material. The $\Delta t$ spikes seen with the gamma-ray highs indicate weak zones. The gamma-ray log recorded with the neutron log shows the following zones of high gamma intensity: $3216 \mathrm{~m}, 3277$ $\mathrm{m}, 3414 \mathrm{~m}, 3453 \mathrm{~m}, 3640 \mathrm{~m}, 3679$ to $3694 \mathrm{~m}$, and 3746 to $3847 \mathrm{~m}$. The neutron log shows large values (high API units) associated with high gamma-intensity zones. This indicates that these zones have little or no porosity and differ from the surrounding rock.

The density log shows spikes of low density from 3170 to $3854 \mathrm{~m}$. The acoustic $\log$ extends only to $3487 \mathrm{~m}$. It also shows acoustic spikes (decrease in velocity or increase in $\Delta t$ ). These indicate weak zones, fractures, and possibly lithologic changes. The caliper log acquired with the temperature log indicates a reasonable diameter and smooth borehole that should not cause any problems for interpreting the density or neutron logs. The density ranges in the 2.80 to $2.55 \mathrm{~g} / \mathrm{cm}^{3}$ are satisfactory, but zones of 2.5 (at 3383 to 3414 $\mathrm{m}$ ) and 2.4 to 2.5 (at 3571 to $3603 \mathrm{~m}$ ) are weak zones representing old healed fractures or changes in lithology. This hole intersects both weak fractured zones and strong zones having little or no porosity.

In summary, the crystalline rock from $3170 \mathrm{~m}$ to a total depth of $3854 \mathrm{~m}$ (an interval of $684 \mathrm{~m}$ ) is a very interesting target for HDR investigations. Although there are some weak or fracture zones in this portion of the hole, there are no indications of any significant fracture permeability from the drilling record or temperature surveys. The bottom-hole static temperature of $230^{\circ} \mathrm{C}$, a gradient of $54^{\circ} \mathrm{C} / \mathrm{km}$, and a contact with crystalline rock at $3170 \mathrm{~m}$ indicate that drilling another kilometer deeper should be considered. The log data affirm that the deep crystalline rock at the Acord 1-26 well near Roosevelt Hot Springs, Utah, is an excellent candidate for further HDR investigations. 
VIII. OTHER PERTINENT FACTORS

The section including the Acord 1-26 well is fee 1 and leased by MCR Geothermal Corporation. The lease on the surrounding sections has been released to the Roosevelt Hot Springs Corporation. Because the drilling and potential HDR energy-production facilities are on privately owned desert land, major environmental objections to its utilization are not anticipated. Utah Power and Light Company (UP\&L) is constructing a 20-MW plant in the vicinity of Roosevelt Hot Springs, $8 \mathrm{~km}$ away, to use the hydrothermal system production (Rasband 1982). Hence it would be feasible to tie any electrical output from an HDR installation at the Acord 1-26 well to transmittal lines emanating from the Roosevelt Hot Springs power plant. Because the contract between UP\&L and the Bonneville Power Company terminates in 1983, UP\&L is seeking additional inexpensive firm power and supplemental power during peak loads.

IX. CONCLUSIONS

It can be inferred from seismic data that there are large faulted blocks of crystalline rock at depth that can be penetrated for HDR purposes. Drilling records and geophysical logs indicate that the rock within these blocks is especially tight and dry. The best location for a new HDR well would be east of Acord 1-26 and west of Phillips 9-1. In this intervening area, the depth to crystalline rock is shallow, but the rocks are still impermeable and very hot. A hydrofracture test in a large zone of this rock would be extremely valuable. The fracture gradient, instantaneous shut-in pressure, and fracture density could be determined and various tools and techniques could be tested in these promising HDR regimes.

\section{ACKNOWLEDGMENTS}

George R. Keller of the Colorado School of Mines provided valuable insight concerning the local and regional setting of the Acord 1-26 well. MCR Geothermal Corporation was most helpful in supplying logs and other data from this well.

\section{REFERENCES}

Davis, T. L., "Seismic Interpretation of Northeast Milford Seismic Lines 1A-3A, Milford, Utah, 3 p., 1 pl. (1980). 
East, J., "Hot Dry Rock Geothermal Potential of Roosevelt Hot Springs Area," Los Alamos National Laboratory report LA-8751-HDR, 45 p. (June 1981).

Goff, F. and E. R. Decker, "Candidate Sites for Future Hot Dry Rock Development in the United States," J. Volcan. Geotherm. Res., v. 15, 187-221 (1983).

Group Seven, Inc., "The Geophysics of the Roosevelt Hot Springs Area," Consulting report to Geothermal Kinetics, Inc., 15 p., 11 pl. (1978)

"Review of Status of Exploration North and East of Milford, Utah, Consulting report to Geothermal Kinetics, Inc., $16 \mathrm{p.,} 15 \mathrm{pl}$. (1979).

Mower, R. W. and R. M. Cordova, "Water Resources of the Milford Area, Utah, with Emphasis on Ground Water," Utah Department of Natural Resources Technical Publication 43, 106 p. (1974).

Rasband, L., "Wellhead Geothermal Development Activities, Roosevelt Hot Springs Geothermal Reservoir," Proceedings of EPRI 6th Annual Geothermal Conference and Workshop, June 28-July 1, 1982, p. 2-1 - 2-2 (1982). 